\title{
Regional Investment Policy: Choosing Priorities and Mechanisms of Interaction
}

\author{
Irina R. Ruiga* \\ Siberian Federal University \\ 79 Svobodny, Krasnoyarsk, 660041, Russia
}

Received 28.07.2017, received in revised form 11.12.2017, accepted 15.12.2017

The article investigates current mechanisms of activating investment activity in the Krasnoyarsk Krai. It presents the analysis of the main indicators of the investment sphere of the Krasnoyarsk Krai, reveals a number of negative trends in the investment process from the point of view of strategic development of the regional economy. Financial and non-financial instruments and methods implemented within the framework of the current investment policy, as well as the legal and regulatory framework they are functioning through, are considered. The paper reveals advantages and disadvantages of the existing measures of state support for the investment activity, indicates the necessity of reviewing the directions of the implemented investment policy in the region, taking into account the world experience and the established positive practice of the subjects of the Russian Federation.

Keywords: investment process, regional investment policy, investment mechanisms, Krasnoyarsk Krai.

DOI: 10.17516/1997-1370-0190.

Research area: economics.

\section{Introduction}

In modern conditions the problem of stimulating fixed assets formation still remains urgent for the Russian regions. Despite the intensification of the state investment policy in recent years, many instruments are not fully used, and the mechanisms implemented so far do not give effective results. In the context of the external challenges of the world economy, it is the state that should initiate the development and implementation of mechanisms for activating investment activities that can combine market mechanisms and state support, thereby allowing the accumulation of free resources and redirecting them to strategic sectors.

\section{Relevance of the study}

The Krasnoyarsk Krai is one of the largest industrial regions in the country in terms of gross regional product (GRP) and export. Such results have been achieved, first of all, at the expense of the export-oriented metallurgical complex formed during the period of reforms, as well as through the active implementation of the investment project for the development of the Vankor oil and gas field in the mid-2000s. For 10

(C) Siberian Federal University. All rights reserved

* Corresponding author E-mail address: IRuiga@sfu-kras.ru 
Table 1. Dynamics of the fixed assets formation in the Krasnoyarsk Krai*

\begin{tabular}{|l|c|c|c|c|c|c|c|c|}
\hline \multicolumn{1}{|c|}{ Indicator } & 2009 & 2010 & 2011 & 2012 & 2013 & 2014 & 2015 & 2016 \\
\hline $\begin{array}{l}\text { Investments in fixed assets } \\
\text { (in actual prices), bln rubles }\end{array}$ & 247.8 & 266.9 & 308.6 & 381.7 & 376.9 & 364.0 & 396.9 & 419.1 \\
\hline $\begin{array}{l}\text { In percent compared to the } \\
\text { previous year (comparable } \\
\text { prices) }\end{array}$ & 118.5 & 110.8 & 114.9 & 117.2 & 96.1 & 92.9 & 96.4 & 100.9 \\
\hline $\begin{array}{l}\text { Investments in fixed assets } \\
\text { per capita, thousand rubles }\end{array}$ & 87.478 & 94.278 & 108.902 & 134.286 & 132.26 & 127.45 & 137.78 & No data \\
\hline
\end{tabular}

*According to the data (Official website of the Federal State...).

years (2005-2014) the value of the GRP indicator increased more than by 3.2 times.

The powerful resource and raw materials base, as well as the industrial base, ensures the positioning of the Krasnoyarsk Krai among the 10 leading regions in terms of investment in fixed assets, and also provides for unconditional leadership in terms of this indicator among the regions of the Siberian Federal District. The investment process in the region is quite dynamic. Even in the crisis year of 2009, the scope of investments in fixed assets increased by $18.5 \%$ in comparable prices of the previous year (Table 1).

Reduction of the actual volume of investments in 2013 and in 2014 is due to objective reasons: the completion of construction and the commissioning of the last units of the Boguchanskaya HPP, as well as reduction in investment in the oil and gas sector and metallurgy. Moreover, there was a decrease in investment activity of PJSC MMC Norilsk Nickel, the region's largest industrial enterprise. At the same time, over the past decade, in terms of volume and investment in fixed assets, the Krasnoyarsk Krai retains its absolute leadership in the Siberian Federal District and the presence in the top ten of the investment-active regions of the Russian Federation.

The presence of large representatives of the mining and metallurgical and oil and gas complexes in the region causes the overwhelming share of investments in fixed assets in mining and manufacturing industries (more than $50 \%$, except for 2014 and 2016). In 2016, the following structure of investments in fixed assets was formed in the region by types of economic activity (Table 2).

The largest share (28.8\%) accounted for manufacturing industries. In the context of manufacturing industries, the largest volume of investments was recorded in metallurgy (more than $20 \%$ ).

The share of mining in the structure of investments in the reporting year ranks second in size and amounted to $17.8 \%$. It should be noted that over the past six years, its share has been decreasing annually. At the same time, organizations specializing in the extraction of fuel and energy minerals account for over $90 \%$ of investments in the mining sector.

The largest share $(28.8 \%)$ accounted for manufacturing industries. In the context of manufacturing industries, the largest scope of investments took place in metallurgy (more than $20 \%)$.

The share of mining in the structure of investments in the reporting year ranks second in size and amounted to $17.8 \%$. It should be noted that over the past six years, its share has been decreasing annually. At the same time, organizations specializing in the extraction of fuel and energy minerals account for over $90 \%$ of investments in the mining sector. 
Table 2. Dynamics of investments into fixed assets by types of economic activity

\begin{tabular}{|l|c|c|c|c|c|c|c|c|}
\hline \multicolumn{1}{|c|}{ Indicator } & 2009 & 2010 & 2011 & 2012 & 2013 & 2014 & 2015 & 2016 \\
\hline Agriculture, hunting and forestry & 1.6 & 1.8 & 2.0 & 1.6 & 1.9 & 2.1 & 2.2 & 1.6 \\
\hline Mining & 44.7 & 32.7 & 30.3 & 27.5 & 27.8 & 22.8 & 21.3 & 17.8 \\
\hline Processing industries & 15.6 & 19.7 & 22.2 & 26.4 & 26.5 & 25.6 & 29.7 & 28.8 \\
\hline $\begin{array}{l}\text { Production and distribution of } \\
\text { electric energy, gas and water }\end{array}$ & 13.5 & 19.4 & 14.3 & 12.4 & 14.4 & 13.2 & 8.1 & 8.1 \\
\hline Construction & 4.8 & 0.6 & 1.6 & 1.1 & 0.8 & 0.7 & 0.7 & 1.0 \\
\hline Transport and communications & 7.4 & 9.2 & 11.0 & 13.3 & 11.0 & 14.7 & 16.2 & 15.4 \\
\hline $\begin{array}{l}\text { Operation with real estate, lease and } \\
\text { services }\end{array}$ & 6.8 & 9.2 & 7.7 & 9.5 & 9.7 & 13.9 & 15.3 & 20.8 \\
\hline Other & 5.6 & 7.4 & 10.9 & 8.2 & 7.9 & 7 & 6.5 & 6.5 \\
\hline Total & 100 & 100 & 100 & 100 & 100 & 100 & 100 & 100 \\
\hline
\end{tabular}

* According to the data (Official website of the Federal State...).

On the one hand, the presence of the leading position of manufacturing production in the structure of investment in fixed assets is a positive factor. It is the manufacturing industries that are currently being considered as the main impetus for the strategic development of the national economy. They form a large added value and create the means of production.

However, in this situation it would be not entirely correct to talk about the prospective structure of investments. Processing industries are represented by metallurgical enterprises, which today are engaged in mining (if we talk about Norilsk Nickel and the gold-mining enterprises of the region) and the primary processing of non-ferrous metals (for example, the production of primary aluminum, RusalKrasnoyarsk). For the production of machinery, vehicles, electronic and other equipment, the metals produced in the province are used abroad, thus creating added value not at the territory of the region, but in other countries (Ruiga, 2013).

The main share of investment projects supported and approved for implementation in the coming years, accounts for raw materials projects and projects related to primary processing. The creation of high-tech industries is envisaged in incommensurable proportions. Therefore, it can be argued that the investments in the region do not stimulate innovative development at the proper level (Ruiga, 2016).

In the structure of investments in fixed assets by sources of financing, starting from 2012, there is a tendency of exceeding the share of own funds over attracted resources. At the same time, in the structure of the latter, bank credits begin to gain a specific weight with a simultaneous reduction in the share of budget resources, which is due to the presence (and constant subsequent increase) of the regional budget deficit.

In the total volume of incoming foreign capital to the Russian Federation, the Krasnoyarsk Krai occupies an insignificant share. At the same time, the flows of foreign investment in the region are unstable and discontinuous (Table 3).

The state of instability is observed not only in terms of the amount of money received, but also in relation to the structure. There is no clearly pronounced tendency for the prevalence of a particular type of foreign capital.

Over the analyzed period, other investments in certain years accounted for more than $95 \%$ of all foreign investments $(2008,2011,2013)$. It is noteworthy that in 2010 portfolio investments accounted for the largest share (over $63 \%$ ). The share of foreign 
Table 3. Dynamics of incoming foreign investments to the Krasnoyarsk Krai*

\begin{tabular}{|l|c|c|c|c|c|c|c|}
\hline \multicolumn{1}{|c|}{ Indicator } & 2008 & 2009 & 2010 & 2011 & 2012 & 2013 & 2014 \\
\hline $\begin{array}{l}\text { Foreign investments (total), } \\
\text { thousand US dollars }\end{array}$ & $3,707,441$ & 218,085 & 743,031 & $1,276,725$ & 177,015 & $3,940,604$ & No data \\
\hline \begin{tabular}{l} 
including \\
\hline direct investments
\end{tabular} & 108,279 & 99,110 & 142,290 & 42,191 & 84,430 & 110,826 & No data \\
\hline in \% from total volume & 2.92 & 45.45 & 19.15 & 3.30 & 47.70 & 2.81 & No data \\
\hline portfolio investments & 59,437 & 14,680 & 471,670 & 15,863 & 11,349 & 1,038 & No data \\
\hline in \% from total volume & 1.60 & 6.73 & 63.48 & 1.24 & 6.41 & 0.03 & No data \\
\hline other & $3,539,725$ & 104,295 & 129,072 & $1,218,670$ & 81,236 & $3,828,741$ & No data \\
\hline in \% from total volume & 95.48 & 47.82 & 17.37 & 95.45 & 45.89 & 97.16 & No data \\
\hline
\end{tabular}

*According to the data (Official website of the Federal State...).

Author's note: there is no information on the official statistics on foreign investments in terms of the regions since 2014.

direct investments (which according to world practice is the basis for the country's successful integration into the international capital flow) ranges from $2.81 \%$ to $47.7 \%$. Despite the fact that the inflow of foreign capital into the economy of the region in 2013 grew by 22 times in relation to the indicator of 2012, $92.42 \%$ of the attracted foreign capital in the region accounts for offshore companies (data of the Analytical Review of the National Rating Agenc (Priamye inostrannye investitsii...)).

According to the rating of the investment attractiveness of the regions of RAEX in 2016, the Krasnoyarsk Krai belongs to $2 \mathrm{~B}$ class (medium potential - moderate risk). The key positive feature of the investment climate of the Krasnoyarsk Krai is the stability of its investment potential, among which the most highly estimated are natural resources (predominant), tourism, production, labour and financial potential of the region. Over the past eight years, the region has not fallen below position 10 (Table 4).

An unfavourable factor is the level of investment risk in the region. According to RAEX for the past eight years, the Krasnoyarsk Krai has been holding positions on this indicator from $68^{\text {th }}$ to $36^{\text {th }}$. The main components that determine the high level of regional investment risk are:

- lack of developed infrastructure;
- high transportation costs due to the remoteness of the region from the main centres of consumption of manufactured products;

- severe natural and climatic conditions and difficult terrain;

- a negative environmental situation in a number of cities (Norilsk, Kansk, Achinsk);

- high crime rate.

In 2016, the Krasnoyarsk Krai improved its position on the total risk rank, rising from the $43^{\text {rd }}$ position (2015) to the $39^{\text {th }}$.

In connection with the presence of these disproportions in the investment sphere, the region is less likely to move to a higher class of investment attractiveness, "high potential moderate risk", which has already been appropriated to the Krasnoyarsk Krai in 2011.

In connection with the presence of these disproportions in the investment sphere, the region is less likely to move to a higher class of investment attractiveness, "High potential moderate risk", which has already been appropriated to the Krasnoyarsk Territory in 2011.

Starting from 2014, the Agency for Strategic Initiatives launched the National rating of the investment climate in the subjects of the Russian Federation. Based on the results of the pilot approbation of this rating, the Krasnoyarsk Krai 


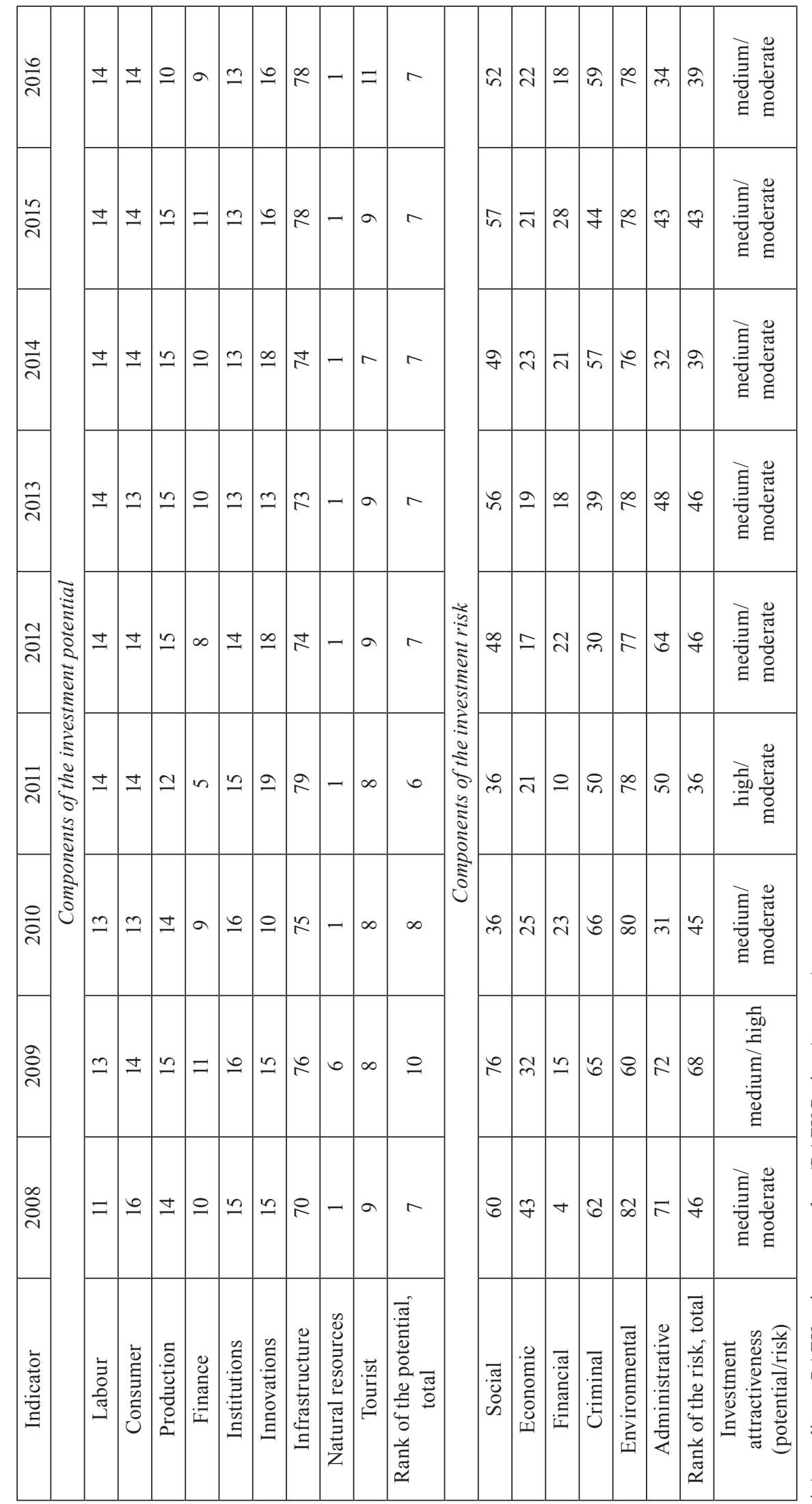

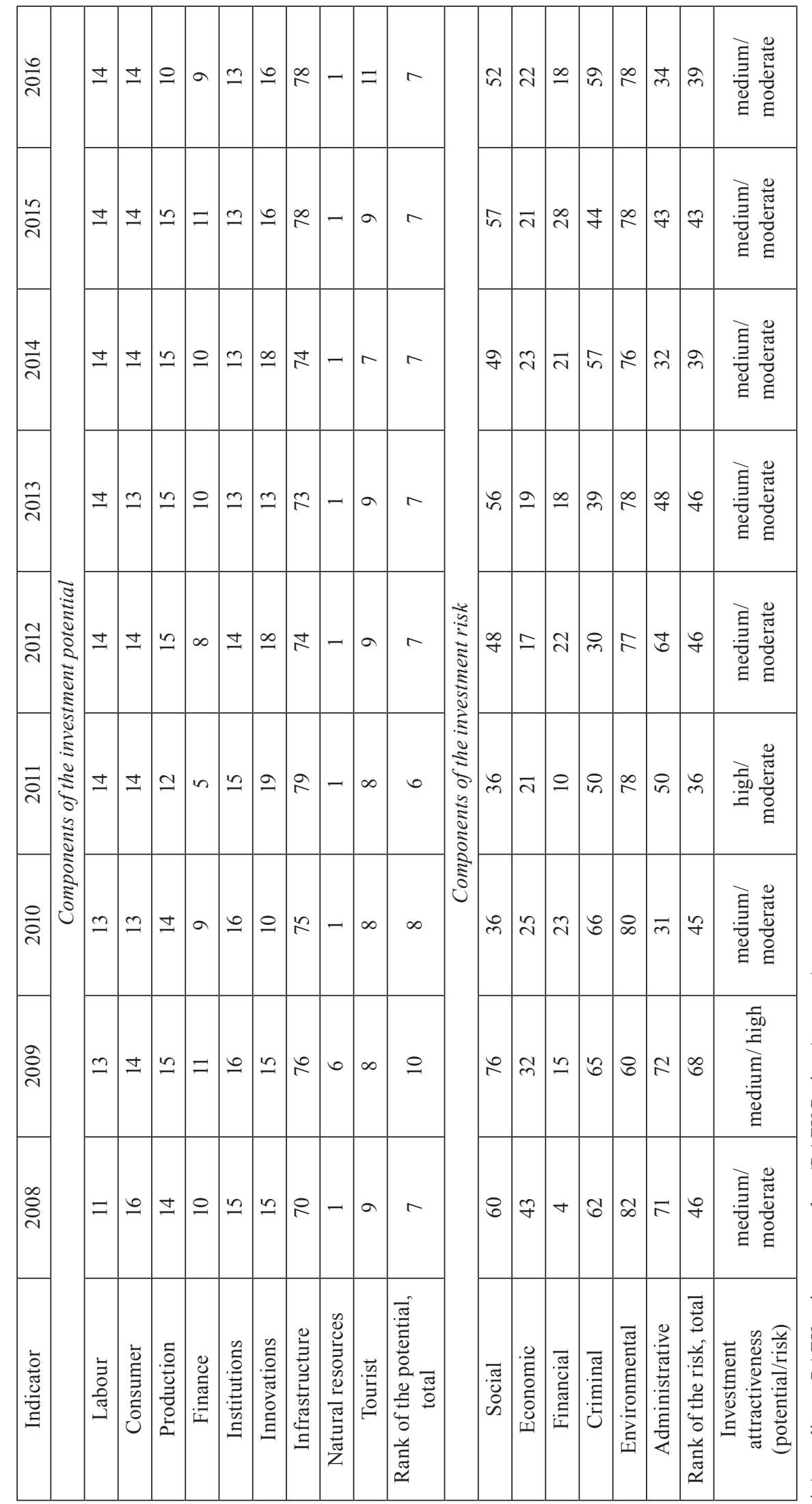

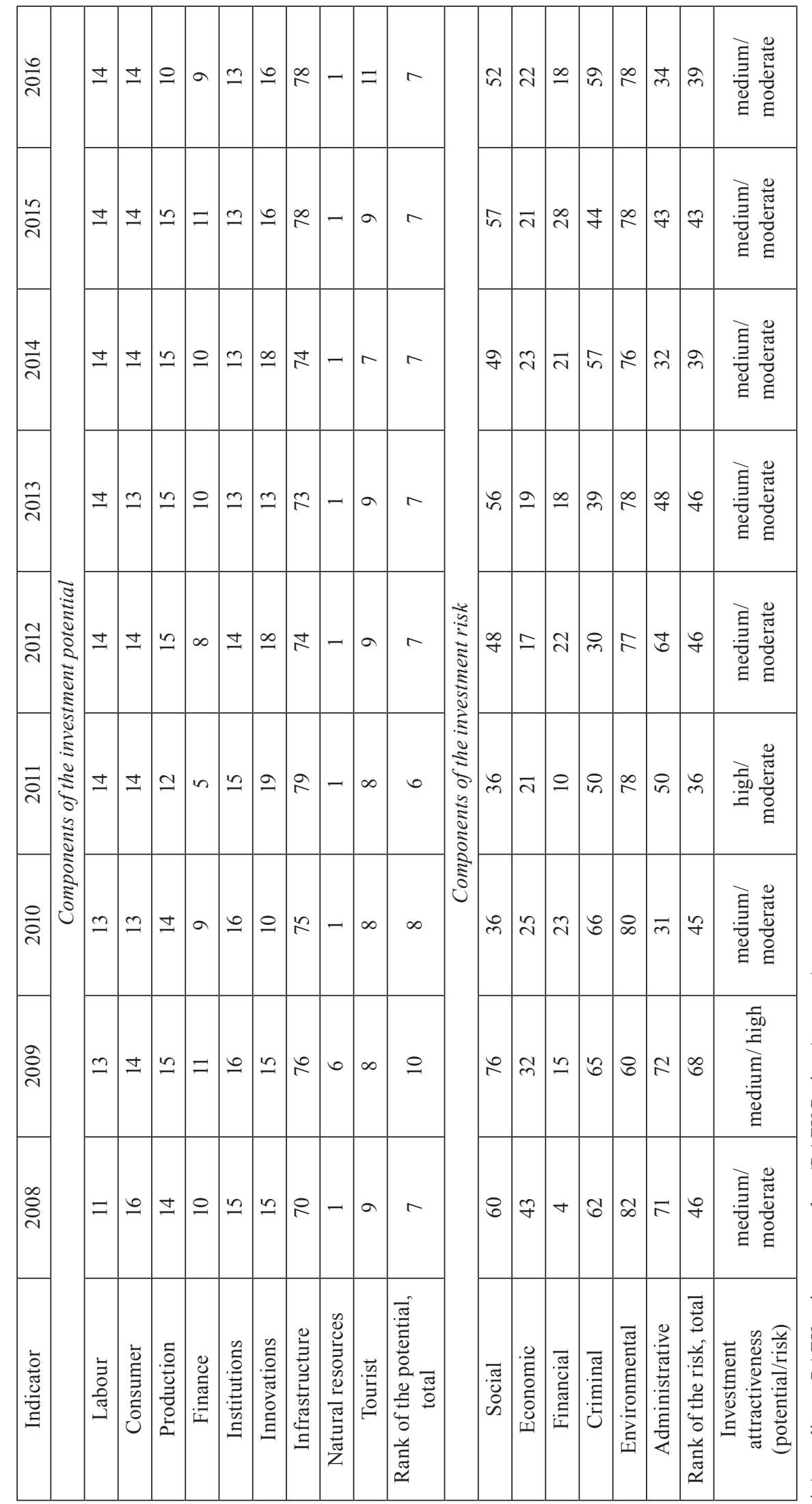

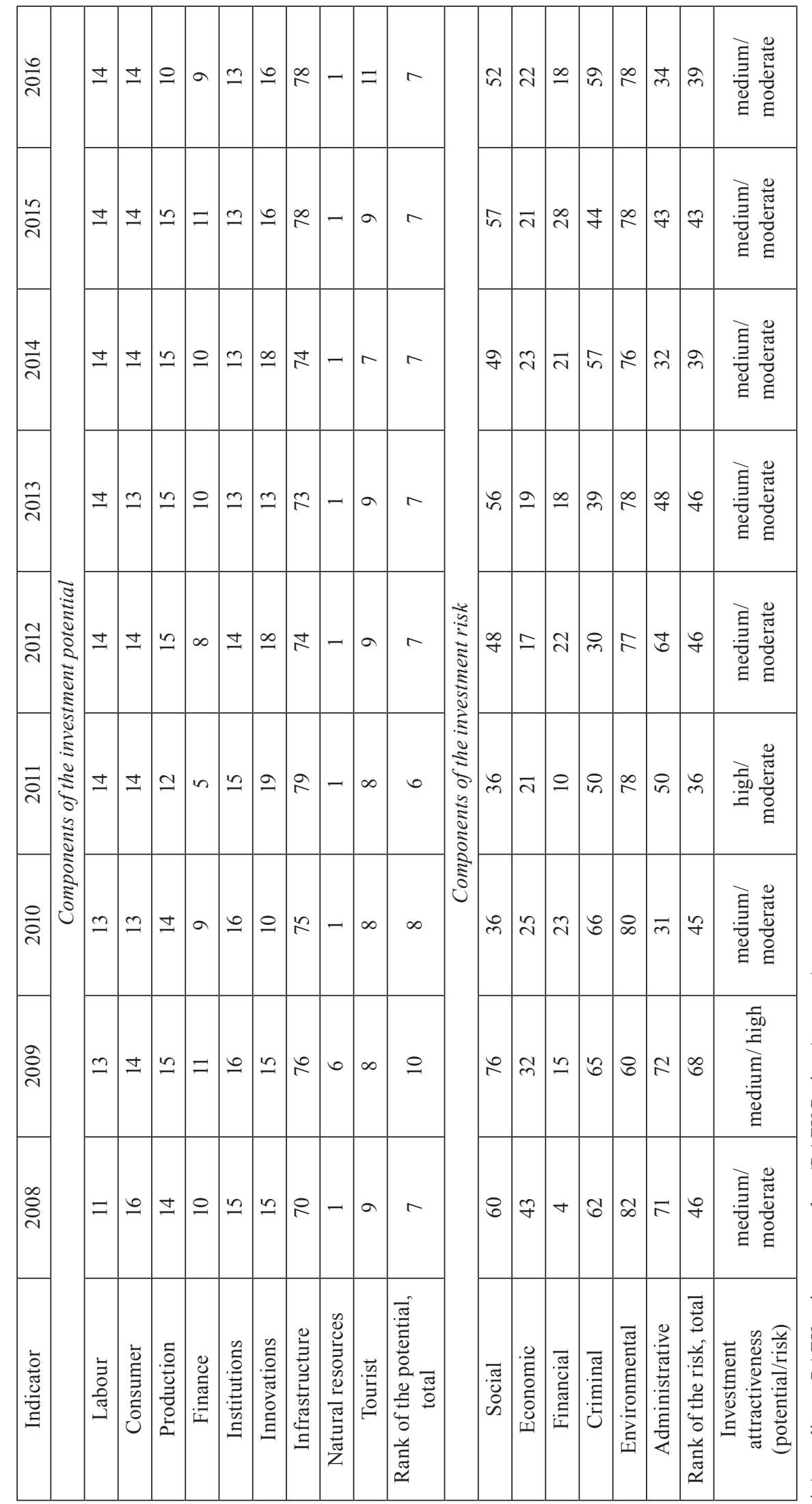

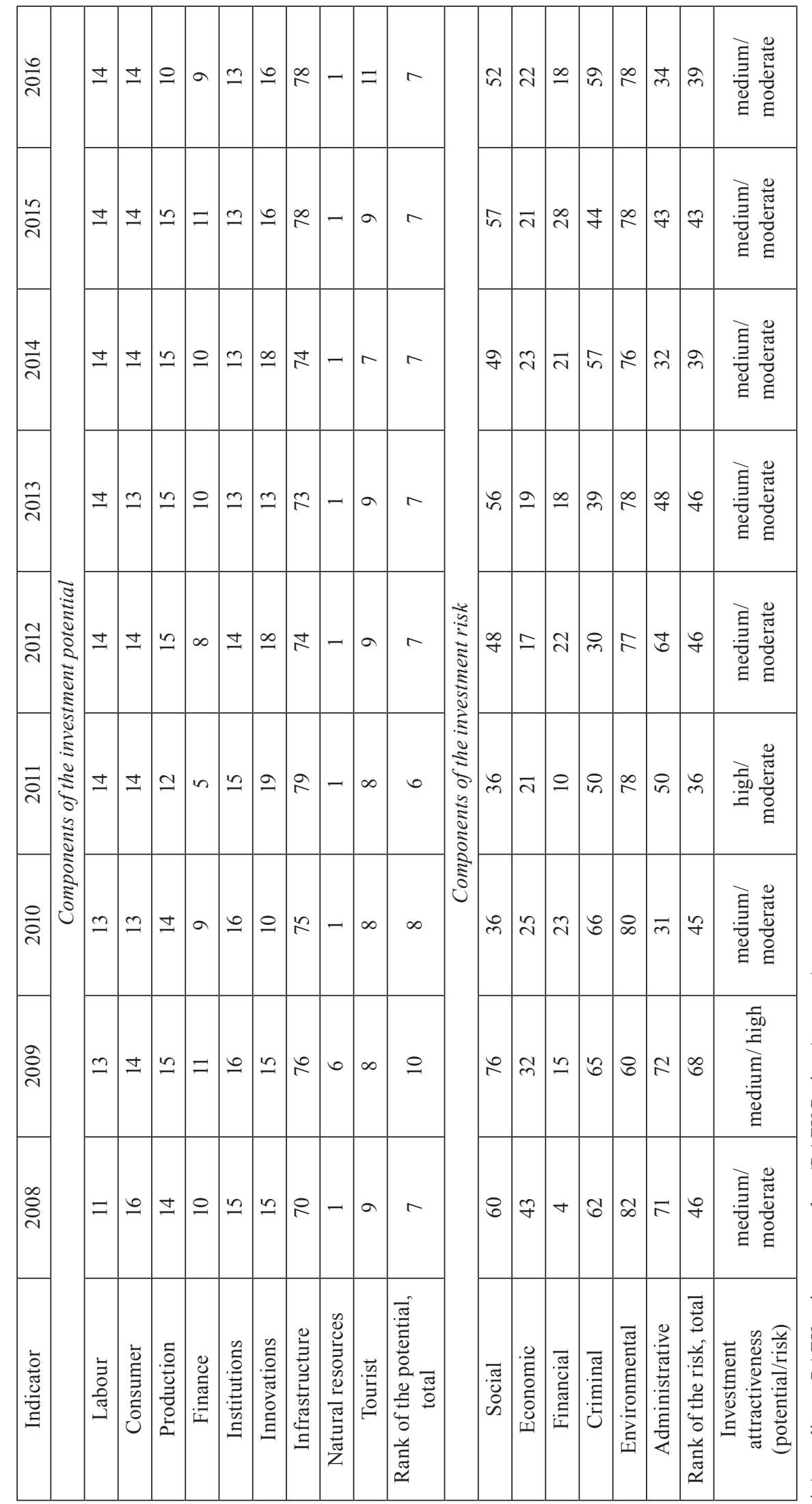

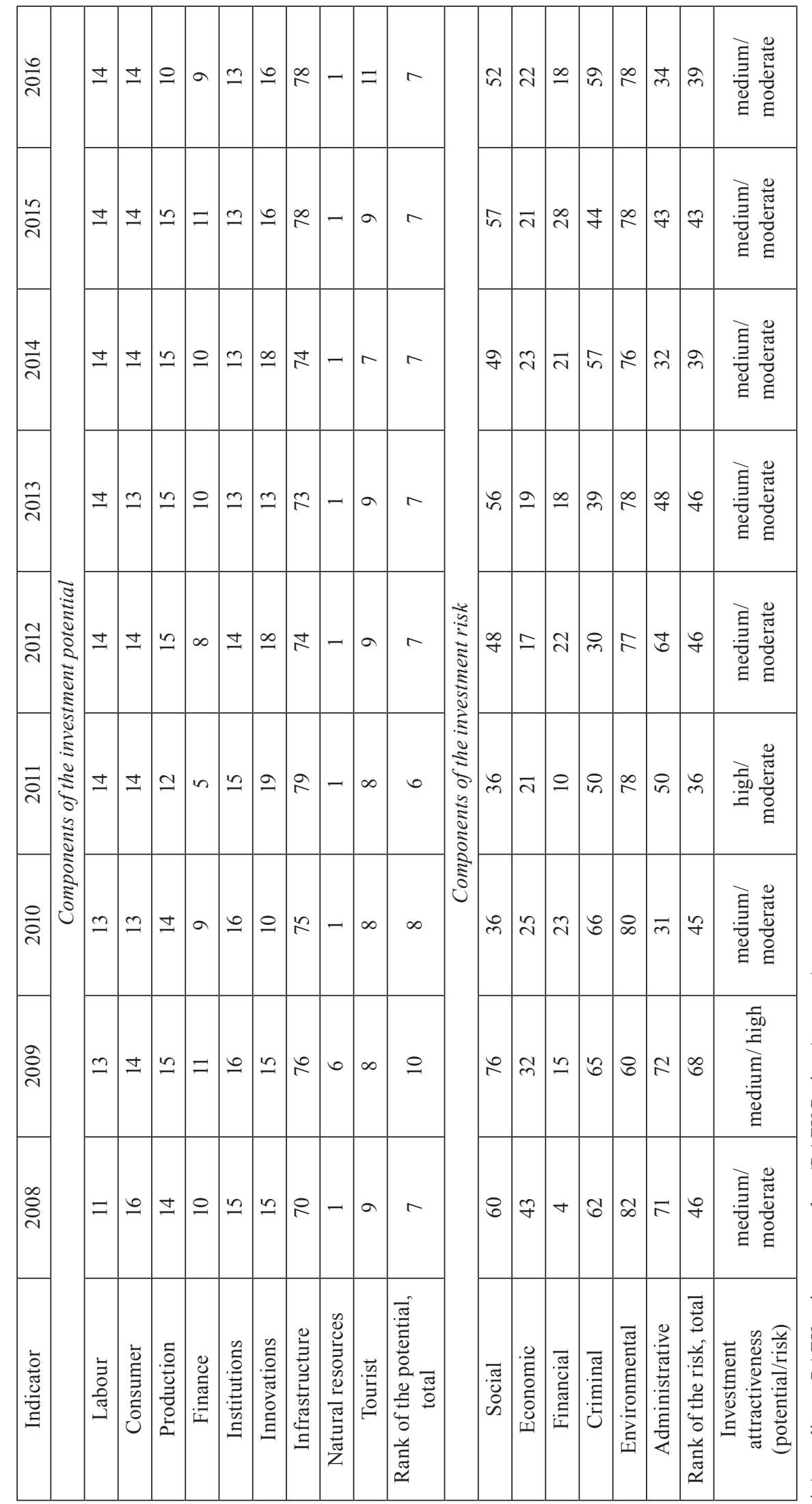

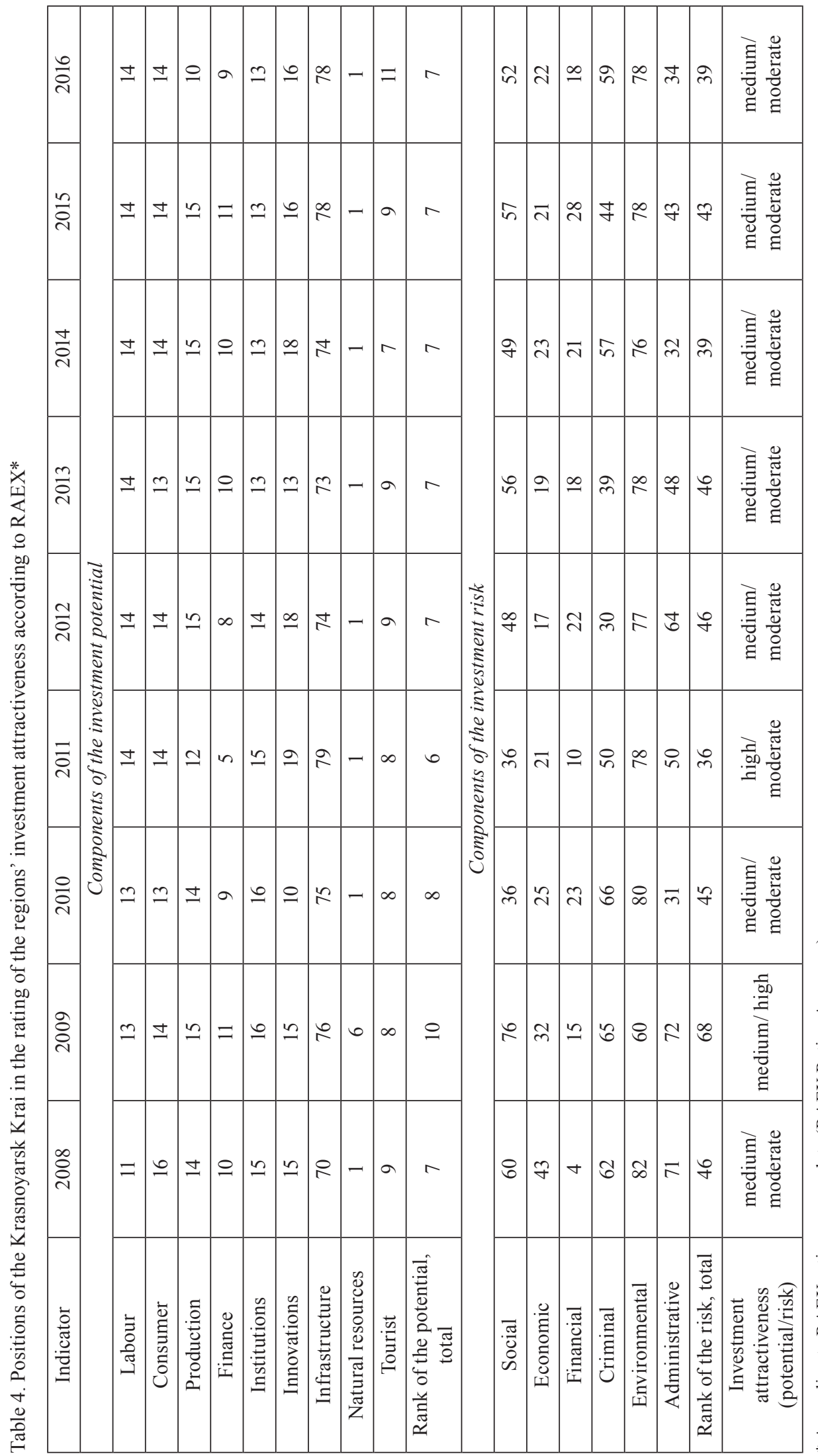

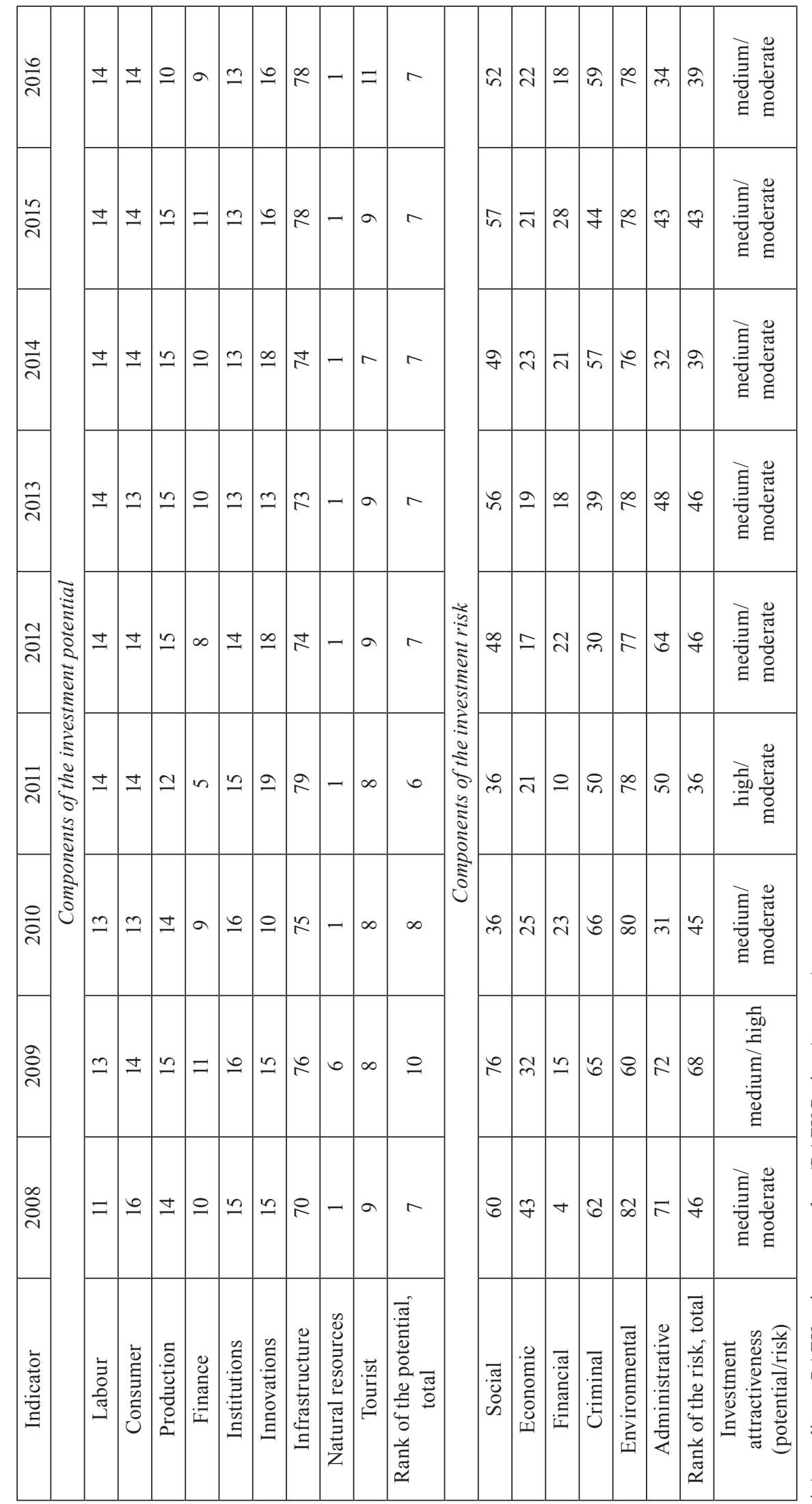

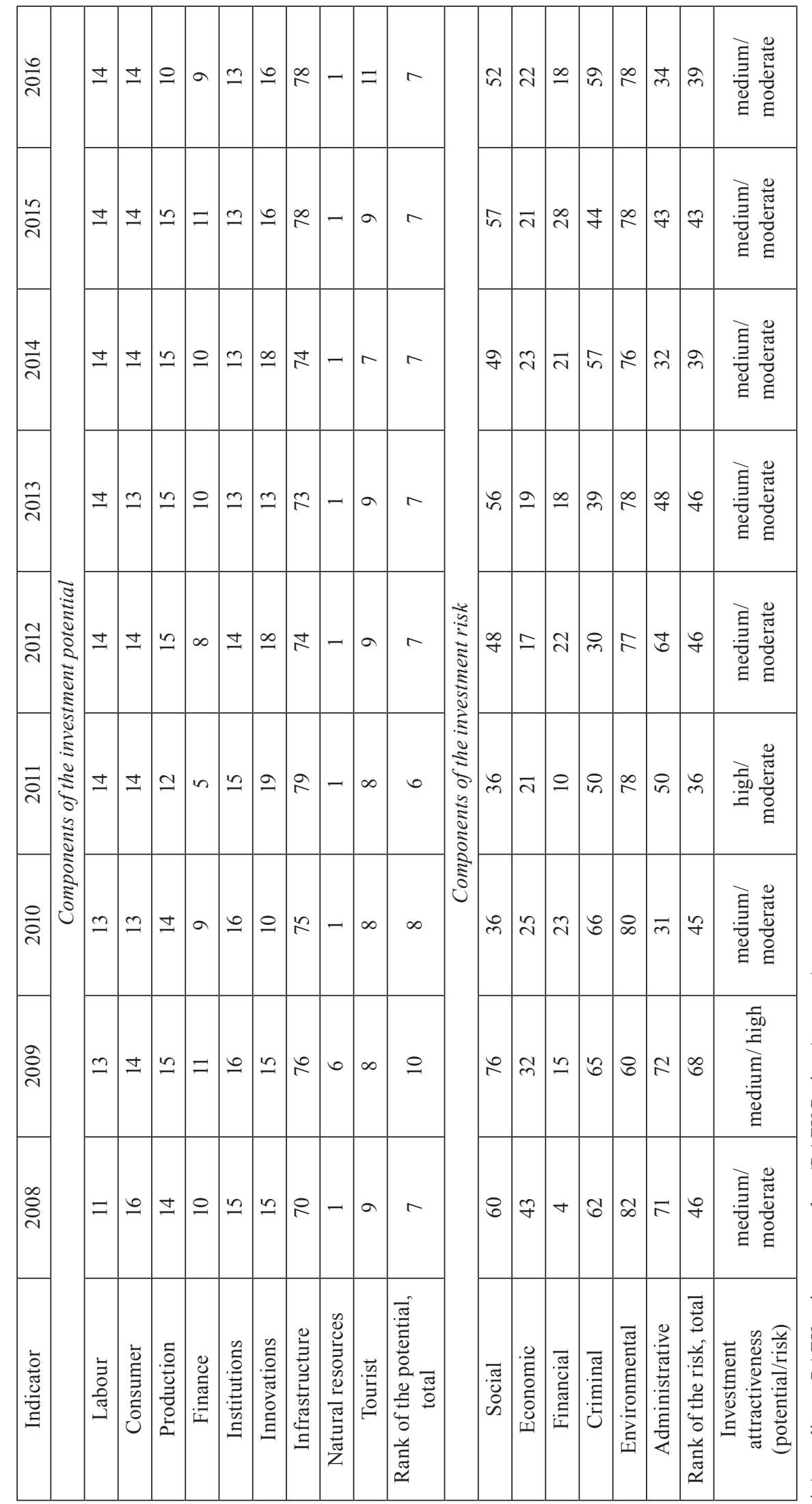

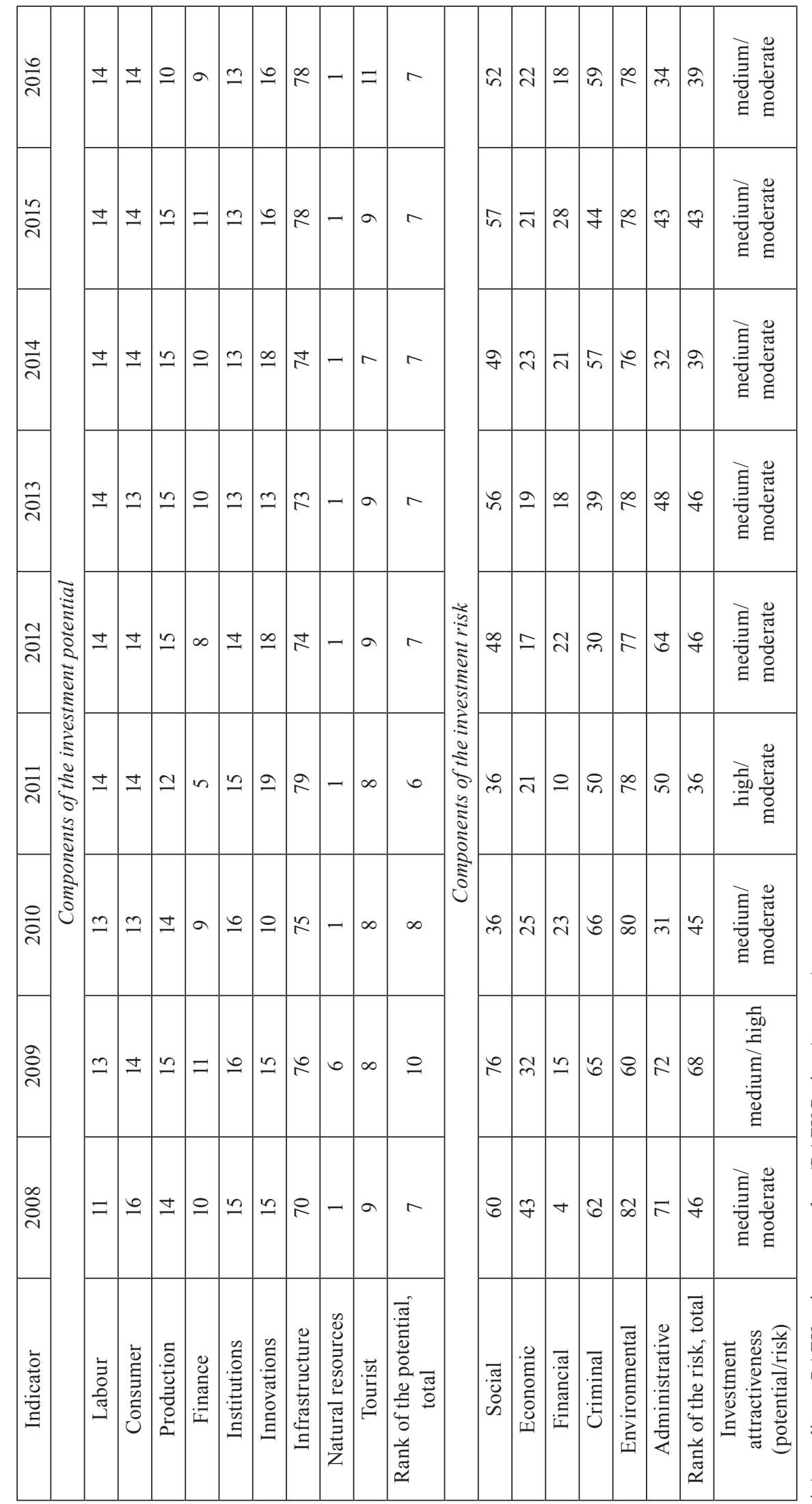

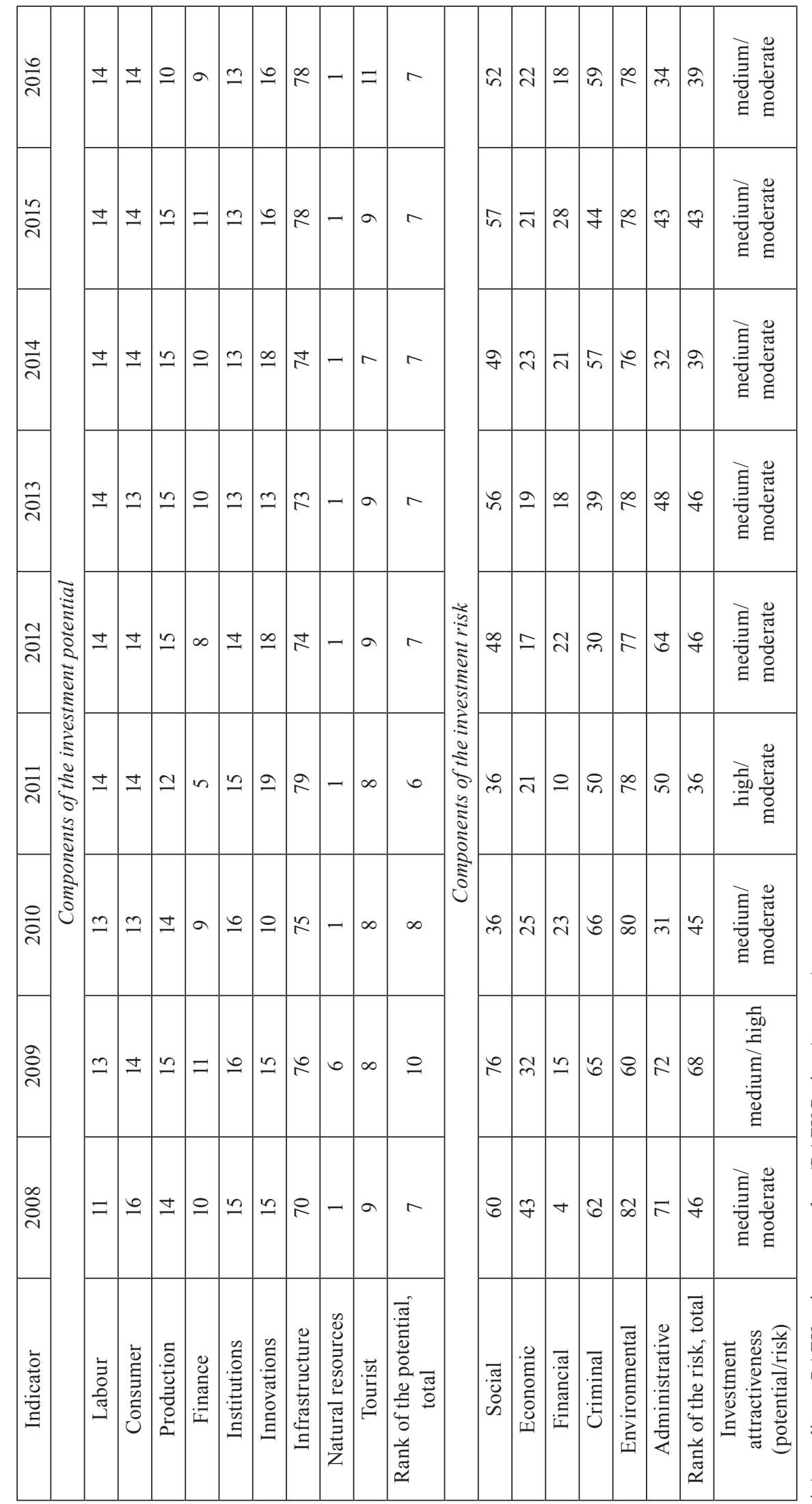

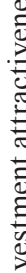

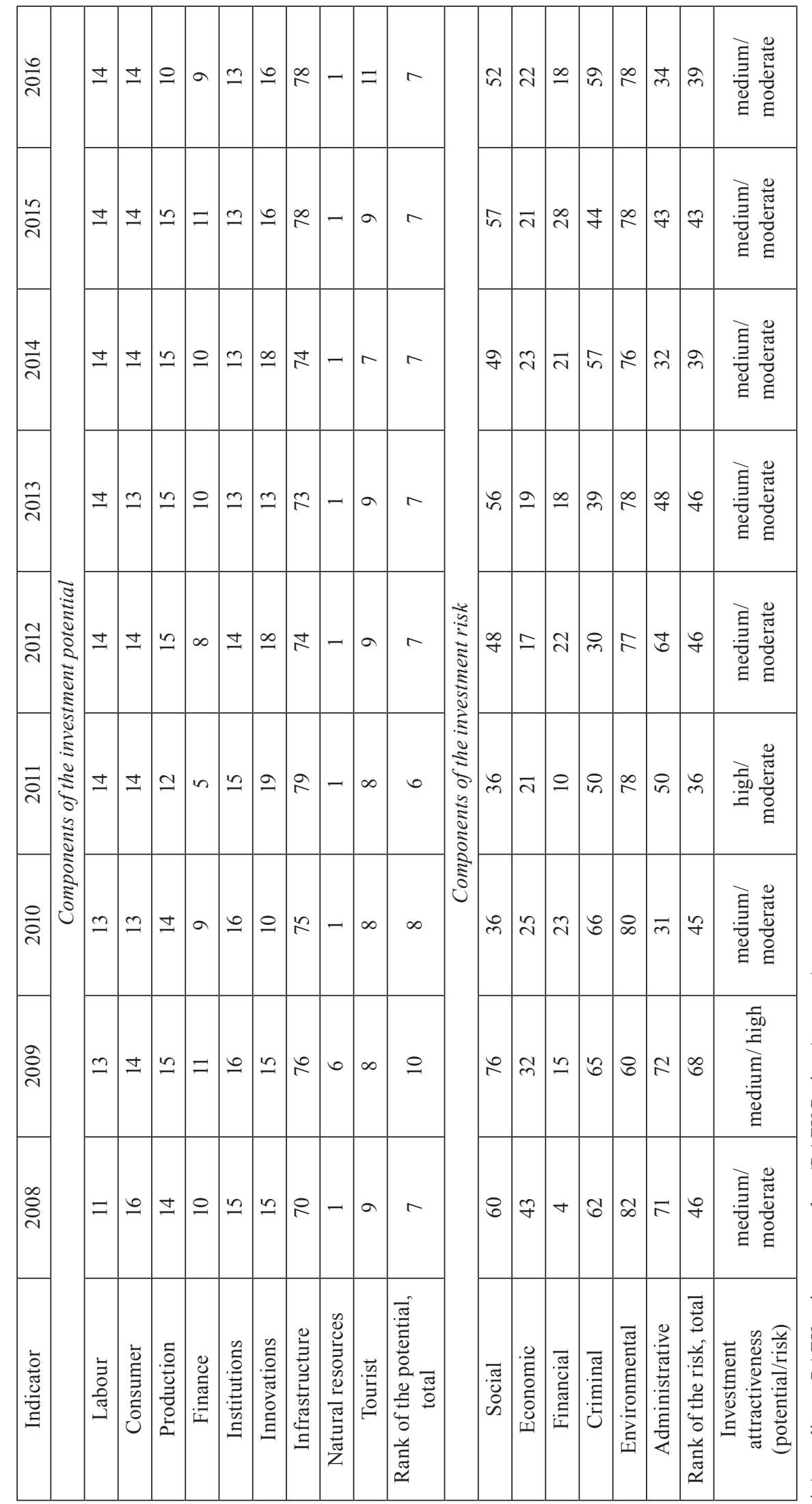

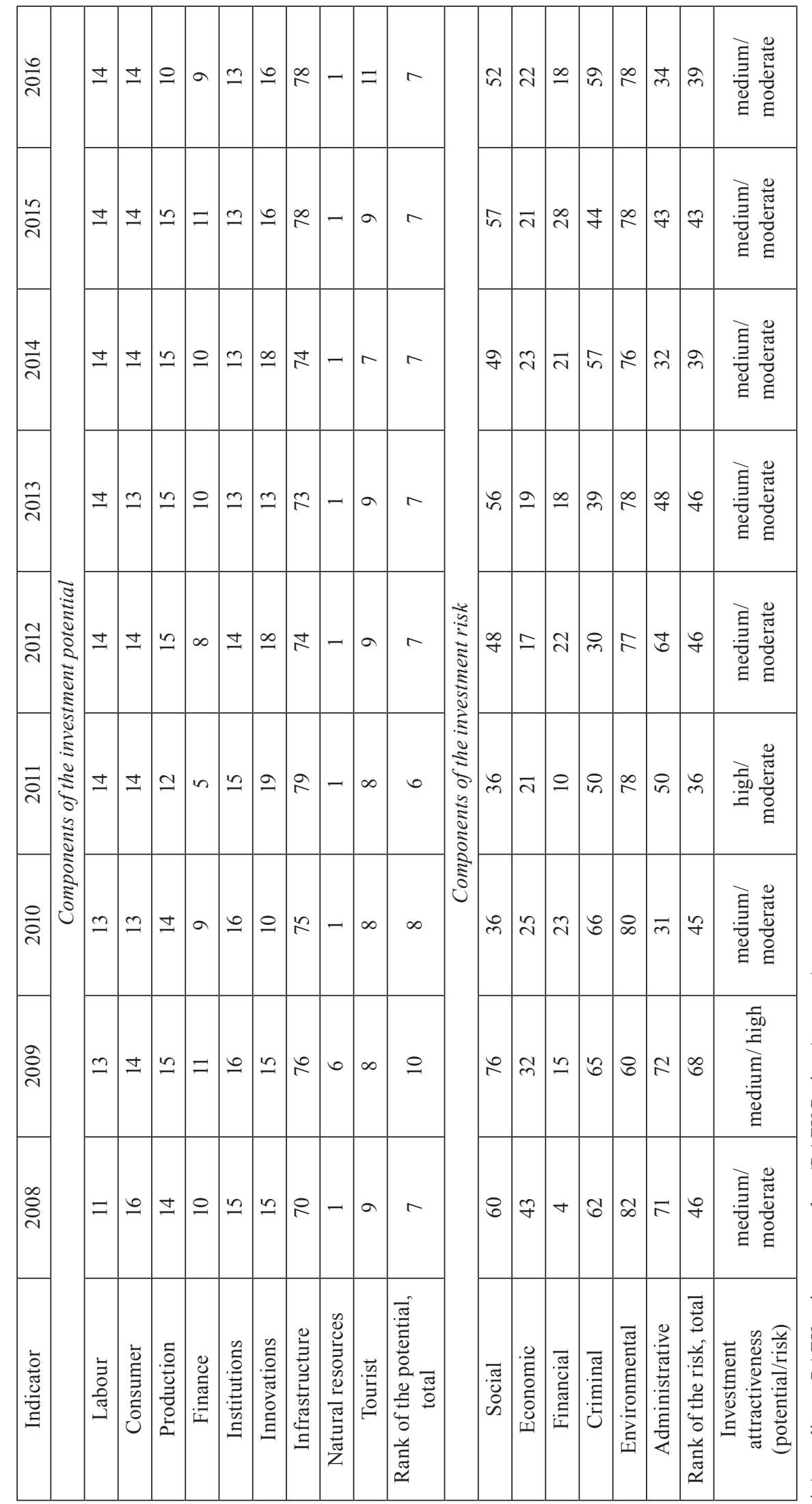

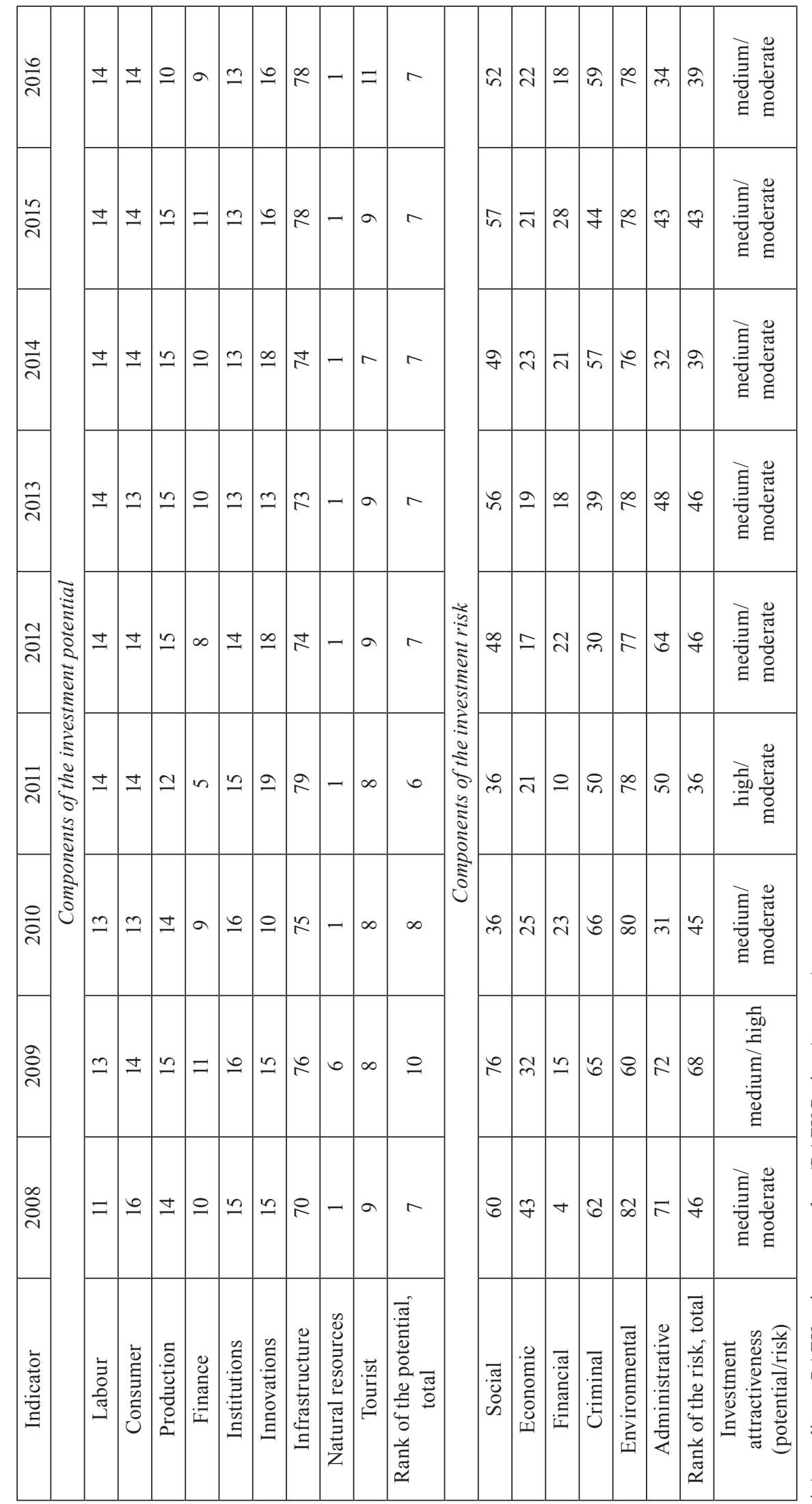

总

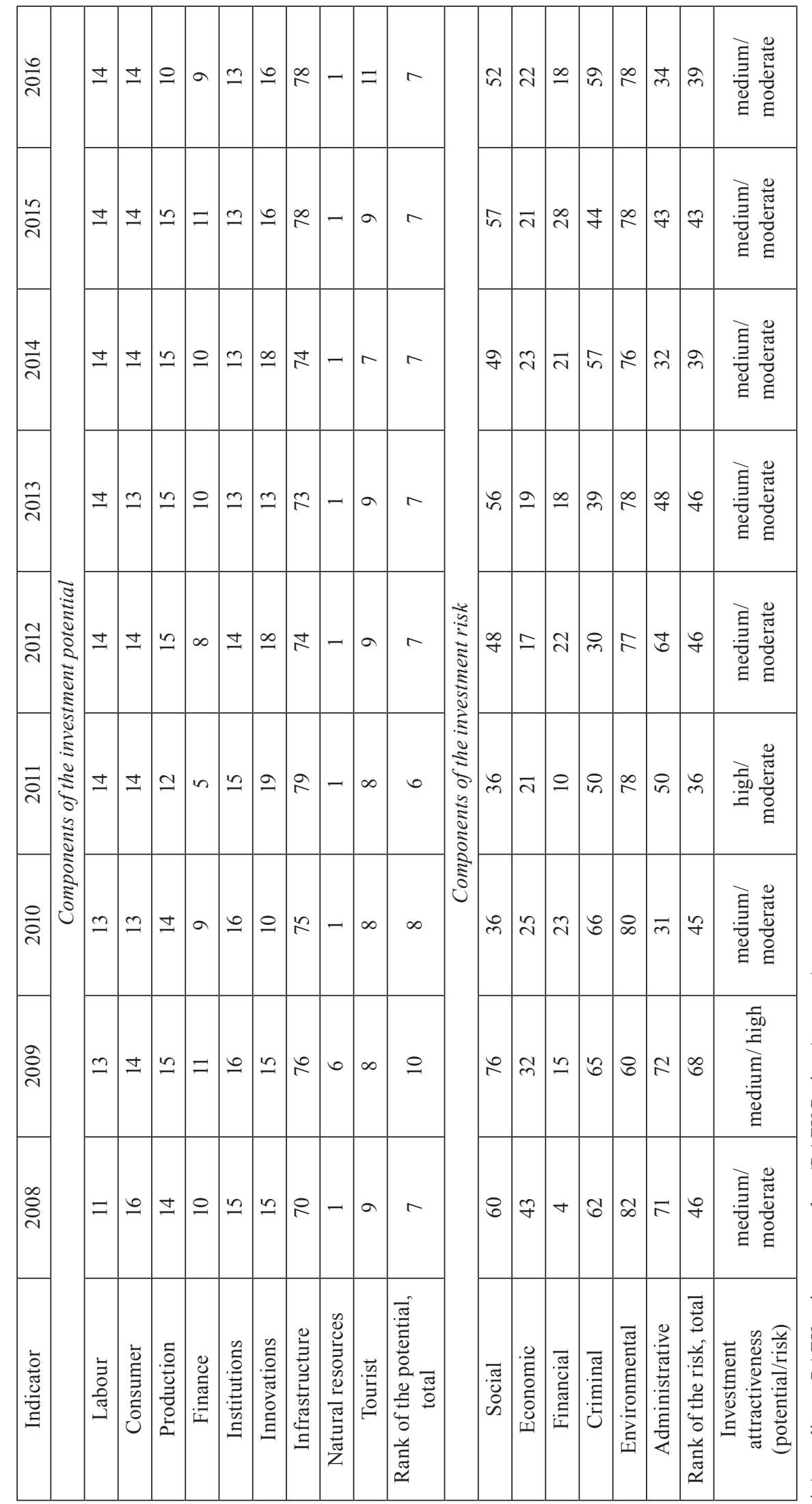

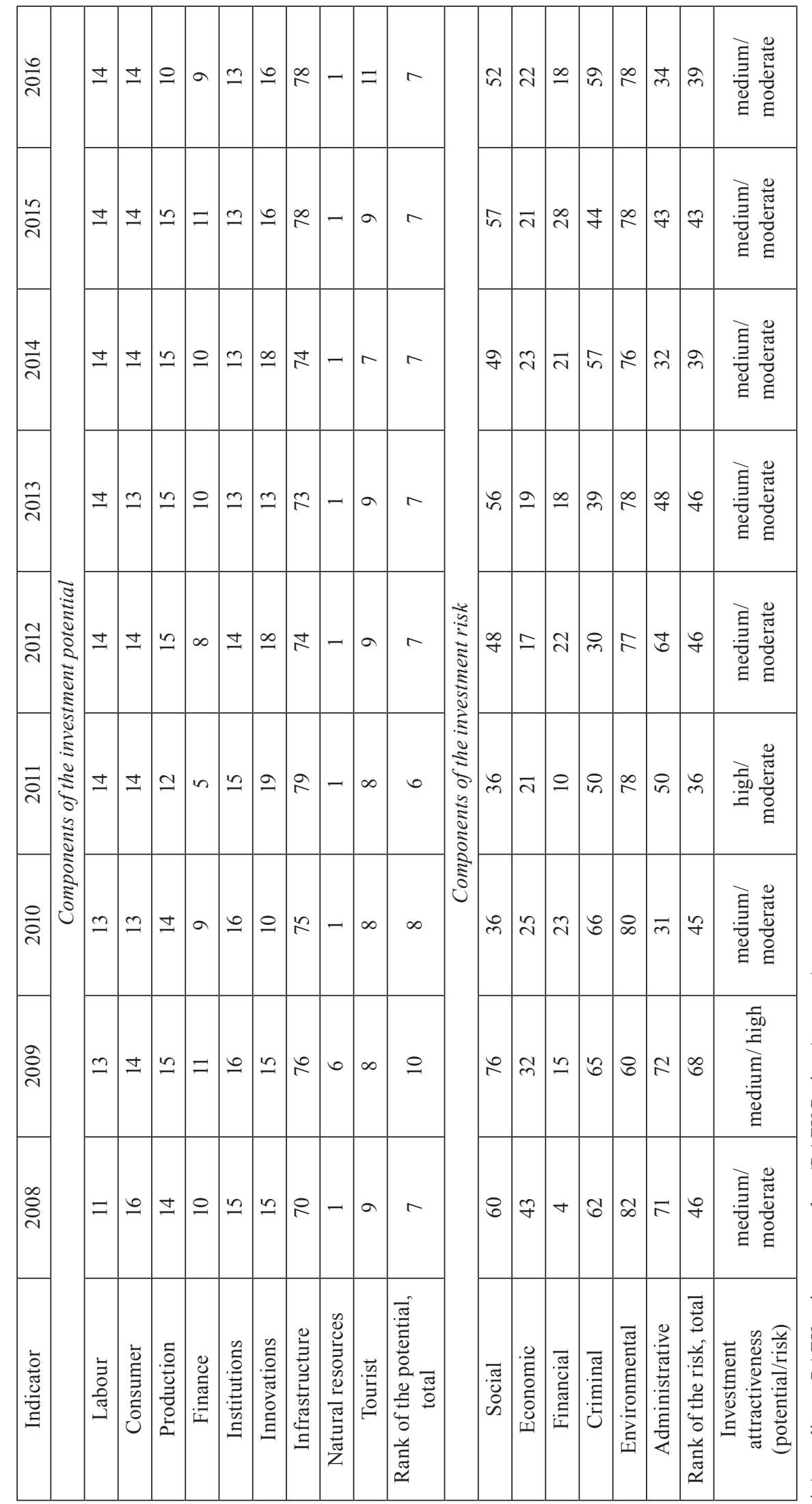

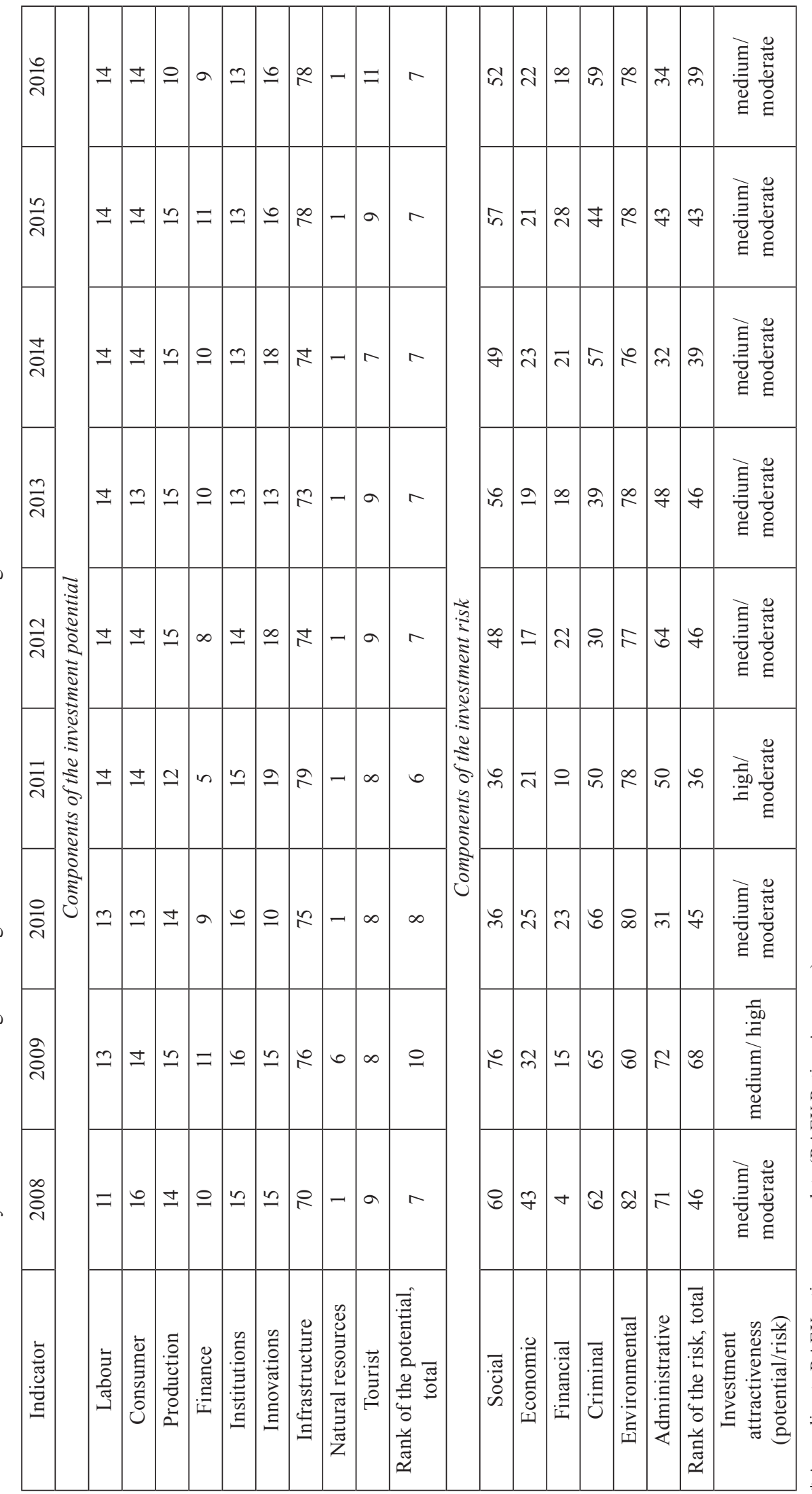

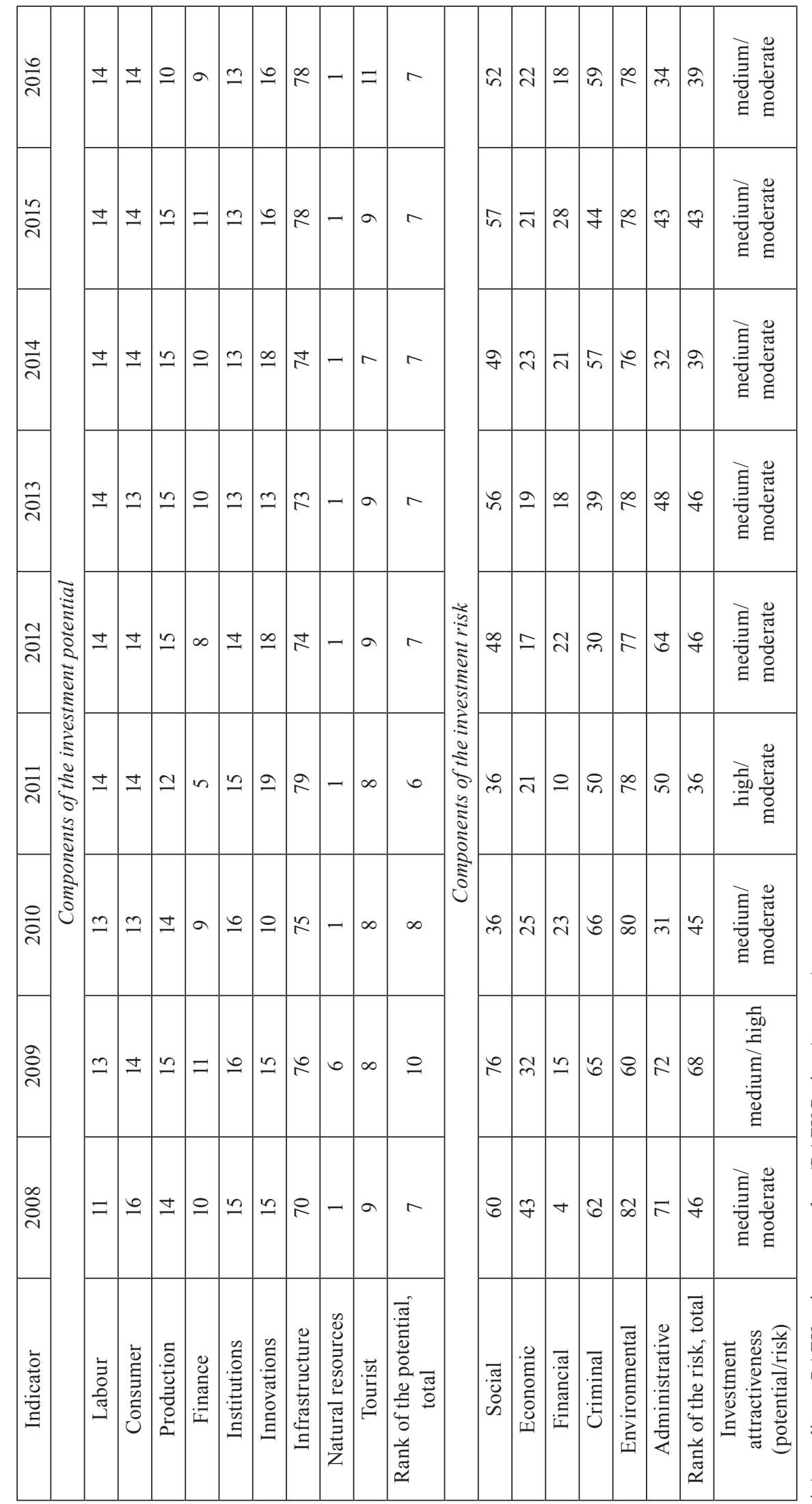

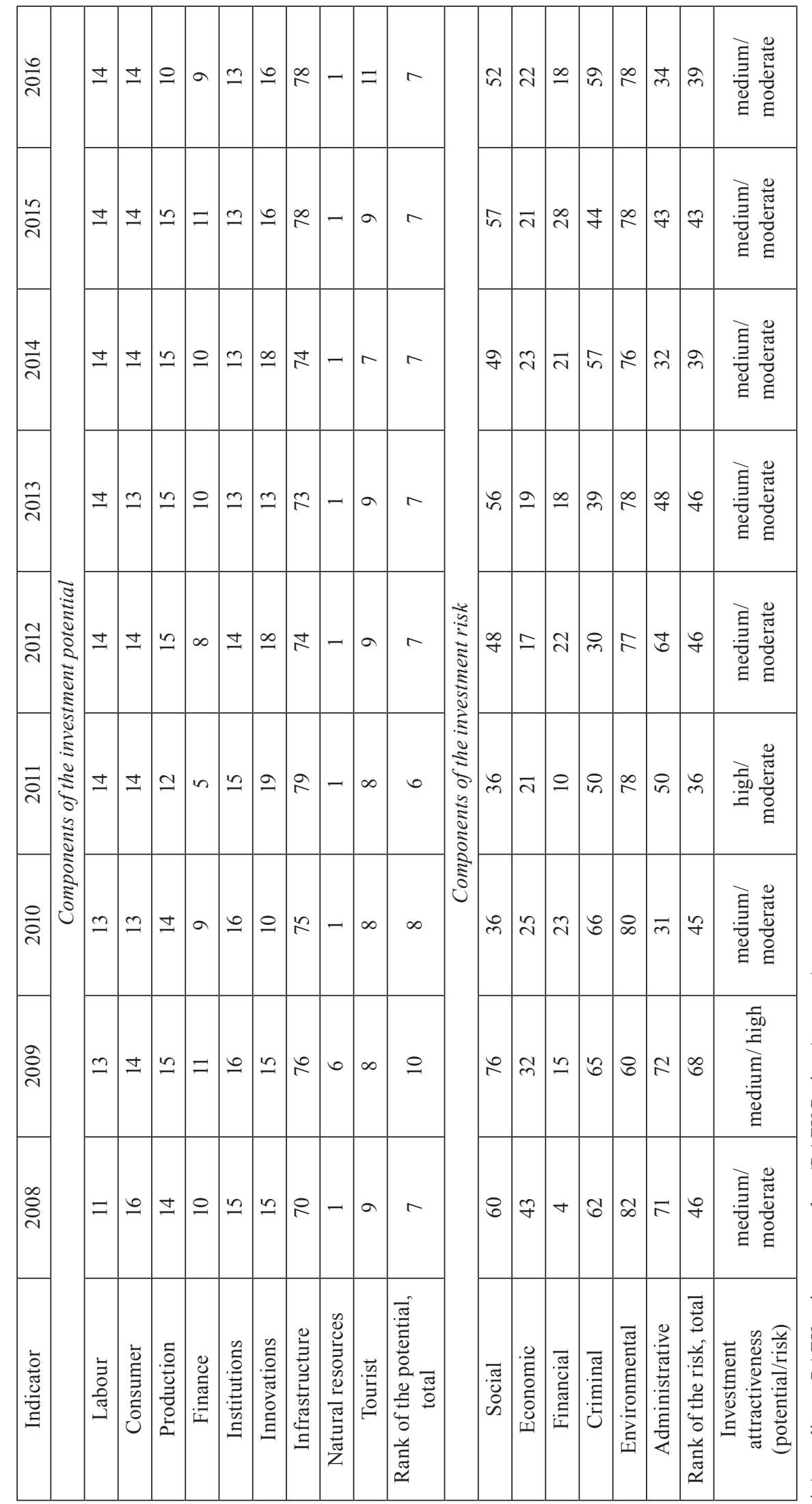

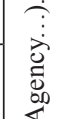

$\Xi$

$:$ 
took the $3^{\text {rd }}$ position among 21 surveyed regions, having received the highest ratings along with the Kaluga and Ulyanovsk regions. As a result, the Krasnoyarsk Krai was the first in the rating of the regions of the SFD for investment attractiveness.

The leading positions of the region are largely due to the implementation of the main provisions of the "Standard of performance of executive authorities of the subject of the Russian Federation to ensure a favourable investment climate in the region" developed by the Agency for Strategic Initiatives in 2011, and laid down in the basis of the 2014 rating.

However, in 2015, the Krasnoyarsk Krai took the $61^{\text {st }}$ position from 76 regions in this rating. On the one hand, we can say that the methods for calculating rating indicators exclude the possibility of an objective assessment of the rating system indicators, since a significant part of them is based on a survey of respondents. On the other hand, a significant drop in the rating makes the assumption that there are no effective mechanisms for activating investment activities and state support at the regional level. At the end of 2016, the Krasnoyarsk Krai improved its position, rising to the $40^{\text {th }}$ position.

Thus, along with the leading positions among the regions of the Siberian Federal District, a number of negative trends in the investment process are currently observed in the Krasnoyarsk Krai in terms of the strategic development of the regional economy (Ruiga, 2015):

First of all, the determining importance of the resource factor (the focus of large industrial enterprises on the mining industry and primary processing sectors) in investment attractiveness is due to the presence of structural disproportions in the regional economy and the decline of processing (technological) sectors.

Second, as a result of the existing organizational structure of large enterprises of the region (the decision-making centre is located outside the region), dependence on external factors causes a low level of control over investment flows by regional authorities.

Third, the peculiarities of the ownership structure of large regional companies lead to the centralization of financial resources at the federal level, the export of capital from the region or the loss of potential investment resources.

Fourth, natural rent from the resources of the region is used by a limited number of persons, and they are located outside the region. Moreover, there is practically no compensation for the deterioration of the ecological situation in the region or the exhaustion of natural resources.

Fifth, foreign investments, as in many other Russian regions, still do not play a significant role in regional economic development.

Against the background of a decline in investment activity in the region, there has been a decline in the growth rates of the gross regional product and industrial production index, as well as the stable negative dynamics of foreign trade turnover that has been outlined in recent years and the growing trend of budget deficit.

These problems predetermine the necessity of revision of tools and methods of the regional investment policy.

\section{Discussion}

Currently, the state support of investment activities and the implementation of the mechanism of public-private partnership are declared as the main directions of the investment policy in the Krasnoyarsk Krai.

Analysis of the current regional investment policy allows us to conclude that there is a sufficiently developed investment legislation. The legislative framework in this area is represented by a number of normative legal acts that determine the legal and economic bases of investment activities in the region. 
In accordance with the current legislation, state support for investment activities in the region should provide the most-favoured-nation treatment (MFN), which is implemented by providing investors with: tax benefits; state guarantees of the region; budget investments in the authorized capital of legal entities; budgetary credits; investment tax credits; privileges for the lease of real estate; subsidies for reimbursement of a part of the interest rate to recipients of loans in Russian credit institutions for the implementation of investment projects.

At the same time, the national mode has been established for foreign investors, regardless of the investor's country. The Government of the Krasnoyarsk Krai decides to grant state support on the basis of the application submitted by the investor and the necessary package of documents sent to the Investment Council, a specially created authority in 2005. The procedure for providing state support for investment activities to business entities in the Krasnoyarsk Krai is rather systematized and regulated. To assess the effectiveness of capital investments, clear criteria for the evaluation of investment project selection, including the applicant's financial status, economic, social and budgetary efficiency, have been developed and legally regulated.

Thus, the possibility of granting the mostfavoured-nation treatment is associated with a successful return on the invested funds for the enterprise that implements the investment project and the budget of the region. However, this approach, although it provides for the longterm provision of financial resources, does not form the direction of investment flows to those sectors that are significant from the point of view of the strategic development of the economy of the region.

Moreover, in most cases, there are no standards (specific values of these indicators or their limits/margins, taking into account the industry and the size of the enterprise), which should be met by the indicators. Thus, in fact, the decision to select investment projects remains with the regional authorities. At the same time, the creation of a special body - the Investment Council - is a positive moment, as it allows one to collect information in one place while working in close coordination with the economic services of the regional government.

The main form of implementation of publicprivate partnership in the Krasnoyarsk Krai is the OJSC "Corporation of the Krasnoyarsk Krai Development" established in 2006. The declared goals of the Corporation are socially significant and presuppose the direct participation of the state in the management of the Corporation's activities. Initially, the main task of this structure was to manage the implementation of the development project of the Lower Angara region.

However, in accordance with the "Standard of performance of executive authorities of the subject of the Russian Federation to ensure a favourable investment climate in the region" developed by the Agency for Strategic Initiatives in 2011, a specialized organization for attracting investments and working with investors should function on a regular basis in the subject of the Russian Federation. In this connection, in 2013 in the Krasnoyarsk Krai the functions of this specialized company were delegated to OJSC "Corporation of the Krasnoyarsk Krai Development".

Currently, this company:

- does not provide an opportunity to provide a "one window" mode for investors when interacting with the executive authorities;

- does not support the creation of project teams to support and implement specific turnkey investment projects, as well as promotion of investment opportunities and projects of the region in Russia and abroad, with the exception 
of only one project - Integrated Development of the Lower Angara Area;

- does not represent the interests of the Krasnoyarsk Krai in public-private partnership projects.

In general, it can be argued that with regard to the use of the mechanism of public-private partnership, the Krasnoyarsk Krai does not show much activity. Despite the adoption in 2011 of a regional law on the development of public-private partnership, it was only declarative. With the adoption of the federal law No. 224-FZ of July 13, 2015 "On public-private partnership, municipalprivate partnership in the Russian Federation ..." the regional law has lost its force.

In the Rating of the Subjects of the Russian Federation on the Level of Development of PublicPrivate Partnership in 2014-2015 the Krasnoyarsk Krai took the $56^{\text {th }}$ position, conceding almost all regions of the Siberian Federal District, except for the Republic of Altai ( $73^{\text {th }}$ position) and the Trans-Baikal Territory ( $74^{\text {th }}$ position). A sharp drop in 2015 in relation to the previous period is associated with a tightening of the criteria for assessing the regions (Table 5).

On the other hand, the increase in the position of 2016 in relation to 2015 occurred practically without changing of the final indicator $(+0.9 \%)$ due to the decrease in the positions of a number of other regions due to changes in the evaluation criteria of the subjects. Thus, the indicator "Investment attractiveness" calculated in 2014 on the basis of the data of the RAEX rating agency was replaced by the indicator "Institutional environment" consisting of 10 indicators, which makes it possible to make a calculation method more focused on the activity of regional administrations for the development of the PPP sphere. In addition, many regions have significantly lost their positions in the rating due to a decrease in the rate of the regulatory framework development. This decrease is due to the entry into force of Federal Law No. 224-FZ, which automatically made regional PPP laws void.

According to the 2015-2016 rating, the Krasnoyarsk Krai occupies the $22^{\text {nd }}$ place among the regions of the Russian Federation according to the indicator "Experience in the implementation of projects", 56 according to the indicator "Regulatory base" and 35 according to the indicator "Institutional environment".

Today in the Krasnoyarsk Krai at the regional level there is no experience in concluding and implementing agreements on public-private partnership. Consequently, the main directions of the development of interaction between the authorities and business in the Krasnoyarsk Krai should be in the sphere of improving the regulatory and legal regulation and institutional environment of PPP projects.

Thus, the main shortcomings of the existing mechanisms for activating investment activities in the territory of the Krasnoyarsk Krai are:

Table 5. Dynamics of the Krasnoyarsk Krai position in the rating of the subjects of the Russian Federation on the level of development of public-private partnership*

\begin{tabular}{|c|c|c|c|c|}
\hline \multirow{2}{*}{ Rating year } & \multicolumn{3}{|c|}{ Indicator } \\
\cline { 2 - 5 } & Position in the rating & $\begin{array}{c}\text { Change of the } \\
\text { position }\end{array}$ & Final indicator & $\begin{array}{c}\text { Change of the final } \\
\text { indicator }\end{array}$ \\
\hline $2013-2014$ & 31 & - & $40.1 \%$ & - \\
\hline $2014-2015$ & 56 & -25 & $29.3 \%$ & $-10.8 \%$ \\
\hline $2015-2016$ & 29 & +27 & $30.2 \%$ & $+0.9 \%$ \\
\hline
\end{tabular}

* According to the data (Federal Information Web Portal...). 
1. Many standards have no practical application, the declared goals are not realized. In particular, this concerns the Corporation of the Krasnoyarsk Krai Development, within which only one project of the Lower Angara region is being implemented so far.

2. Among all the possible forms of state support provided for by regional legislation, interest subsidies on credit resources are mainly implemented.

3. There is a significant disproportion in interaction with different business categories: compared to medium and small business, partnership with large investors has a more significant contribution. As a result, investment activity reflects the interests of owners of large domestic commodity corporations, focused on the use of the region's natural resources. The implementation of large-scale oil and gas, metallurgical and electric power projects is much larger than the volume of investment resources in the development of small business, including innovation. This circumstance can only provoke increasing dependence on large corporations and contribute to the growth of the raw material component in the sectoral structure of the regional economy.

4. There is a high entry barrier for investors, while the region is focused on a relatively narrow range of investors, and mechanisms aimed at large-scale accumulation of the population's funds are practically not used.

5. The functioning of most investment mechanisms is accompanied by a certain information closeness. As a rule, at the initial stage attention is attracted, and further implementation is practically not covered, there is no feedback system and active interaction of potential investors, including the population.

Summarizing the above, we can say that the current mechanisms for activating investment activities in the Krasnoyarsk Krai do not yet allow to overcome, and sometimes intensify, the negative factors of the investment process in the region.

\section{Research results}

In the author's opinion, the existing problems in the investment and innovation field in the Krasnoyarsk Krai can be solved by creating a public-private mechanism for activating innovative and investment activities at the regional level, which should meet the following requirements:

1) ensure sectoral and entrepreneurial diversification of investments in fixed assets, which implies a system of project selection, monitoring of socio-economic development and close interaction (primarily informational) of state bodies with business structures involved in the implementation mechanism;

2) ensure that the incomes earned in region at the expense of available natural resources remain in the region and are invested in the development of related industries, as well as in the development of technological enterprises operating in the region and new directions for high-tech industries on their basis, i.e. ensure redistribution of natural rent in favour of the territory, and not external owners;

3) should be aimed at investors of different levels, respectively, combine all kinds of existing instruments and mechanisms in the field of investment and innovation support that are relevant both for large businessmen and small and medium businesses, and also provide a certain level of profitability to investors through the implementation of activities, for example, in the stock market;

4) the state should take an active position to ensure control in the public-private mechanisms being implemented, as well as the direction of investment flows in accordance with the strategic interests of the region's innovative development. 
In order to improve the mechanism of publicprivate partnership in the Krasnoyarsk Krai, it is necessary to implement a number of trends.

The first one is the inclusion of the mechanism of public-private partnership in the strategic documents of the region.

As part of this recommendation, it should be considered that PPP is not an independent object of the policy of public authorities, but refers to tools for the development of public infrastructure with the involvement of extrabudgetary sources. Thus, consideration of PPP mechanisms in planning documents is necessary in connection with the goals, objectives and priorities for the development of regional infrastructure.

Secondly, according to the authors, one of the most important measures that ensure not a declarative, but the current application of PPP in the subject of the Russian Federation, is the development of a mechanism for interagency cooperation.

Thirdly, in the current conditions of increasing complexity of the overall economic and political situation, increasing level of risks, reduction of investment and innovation activity of enterprises, it is important to encourage investors to implement infrastructure projects based on the PPP principles through the use of tax and non-tax instruments and methods.

In the current circumstances, the author assumes that the main task for the region is to find its own way out of the current situation without reckoning on federal investments or waiting for the launch of any new strategic infrastructural projects initiated by the federal centre.

In turn, the strategy of the "turn to the East" of the Russian Federation, which has been outlined since 2014, creates a potential opportunity for the regions of Siberia and the Far East to build into the system of foreign economic relations of the rapidly growing Asian market with its absolute leader, the People's Republic of China.
The further development of the general economic space of large Asia will be determined by the global world infrastructure mega-project of the PRC announced in 2013 as "One belt, one way". Within the framework of this project, it is planned to create two transport corridors: the "Silk Road Economic Belt" (SREB, the development of trade on land territories connecting China with Europe) and the "Sea Silk Road of the $21^{\text {st }}$ century". If the sea route lies far from the borders of the Russian Federation and traditional zones of influence, the overland route is planned to be implemented through the territories of the former Soviet republics Central Asian countries. At present, the project includes Kazakhstan, Kyrgyzstan, Uzbekistan, Iran, Pakistan, Vietnam, India, Turkey, Hungary, Germany, Kenya, etc.

This project provides countries and regions that have entered into it a unique chance to intensify and modernize their economies through participation in a single global transport and trade network.

The Russian Federation has so far provided only one railway branch, and it is located in its European part. At the same time, the minimum distance from Russia's borders to the key point of the land transport corridor (Urumqi station) is located near the southern borders of the Krasnoyarsk Krai. Thus, an important component of the future programme of joint Russian-Chinese development around the Silk Road Economic Belt should be the inclusion of Siberian regions in the project with its openness to the markets of Asia.

The presence of a world class infrastructure project near the borders of the Krasnoyarsk Krai provides a unique opportunity and obliges to implement an attempt to include the region in the global trade and transport Asian network. However, the Krasnoyarsk Krai does not have obvious competitive advantages for unconditional entry into this world project, except for one - the presence in 
the region of "junction points" to the Northern Sea Route, the ports of Dudinka and Igarka, almost the only ones on the entire Asian part of the route.

The Northern Sea Route is not a part of the New Silk Road project, but it is nevertheless the shortest route from Asia to Europe. China, of course, is interested in the development of the Northern Sea Route. According to some estimates, by 2020-2025 up to $15 \%$ of Chinese exports can be shipped by this route (K Velikomu Okeanu...).

The addition of the the northern land-sea corridor conventionally named (Ruiga et al., 2015) "Silk Meridian of Siberia" (UrumqiDudinka-Rotterdam) to the New Silk Road as a part of the southern sea corridor (ShanghaiRotterdam) and the central overland one (XianDuisburg) will allow to "embed" the Krasnoyarsk Krai in the map of the global PRC project and set an appropriate trend for regional strategic development until 2030 and for the future.

The process of introducing the Siberian region in the system of economic and infrastructural links of the New Silk Road is expedient to implement on the basis of a clearly regulated sequence of actions presented in the form of a corresponding regional programme document. In turn, the accumulated systemic problems hindering the economic development of the region necessitate a review of the main directions of the regional investment policy.

The author considers the following tasks to become the main objectives of the investment policy of the Krasnoyarsk Krai in terms of the Asian vector of the Russian economy development (Ruiga et al., 2015):

1. Inclusion of the region in the number of facilities of the Asian Infrastructure Investment Bank (AIIB) and the New BRICS Bank for investment in the creation of a system of main transport routes.

2. Inclusion of new large and mediumsized industrial projects of the region in the investment plans of foreign states and large private companies of the PRC and leading BRICS and SCO countries.

3. Attraction of Russian public investments on the basis of public-private partnership for the creation of industrial and local transport infrastructure of the lower level that accompanies industrial facilities.

4. Qualitative improvement of the investment climate in the region and creation of favourable conditions for the implementation of investment projects in priority sectors of the economy, including those aimed at the production of innovative products.

5. Assistance in the development of existing and creation of new investment sites.

6. Development of a relevant institutional infrastructure in the form of specific development institutes.

The investment policy of the Krasnoyarsk Krai should include a number of measures aimed at solving certain investment tasks:

- creation of a specialized regional organizations on a regular basis for attracting investments and working with investors (Development Corporations);

- conclusion of an agreement between the Krasnoyarsk Krai Government and the Ministry of Economic Development of the Russian Federation on joint approval of investment project passports to include trade missions of the Russian Federation in the permanent work on attracting foreign investment in these projects;

- promotion and further inclusion of the representative of the Krasnoyarsk Krai in the Russian group in the Boards of Governors of the Asian Infrastructure Investments Bank and the BRICS New Development Bank;

- promotion, presentation and defense of the Krasnoyarsk Krai in the Asian Infrastructure Investments Bank and the BRICS New Development Bank as a candidate for the 
establishment of Siberian regional offices of these banks in the region;

- establishment of permanent investment missions of the Krasnoyarsk Krai in Beijing, Shanghai, Hong Kong;

- establishment of a permanent representative office of the Krasnoyarsk Krai at the International Financial Centre in Astana.

\section{Conclusion}

The author of the article assumes that the implementation of these measures will seriously activate the investment process, which in turn will contribute to the emergence of qualified modern financial management, technical re-equipment and competitiveness of regional business structures in the region. The Krasnoyarsk Krai's market, objectively unattractive due to its negligibly small scale, can get harmoniously incorporated into the giant growing market of neighbouring Asian countries and will become an integral part of it. This will open the region for the transfer of goods, capital and technology from the PRC and the leading BRICS and $\mathrm{SCO}$ countries, will allow to begin the formation of a civilized market and market infrastructure. The production enterprises of the Krasnoyarsk Krai will be involved in the development of international technological cooperation chains, in the system of cooperation ties with the PRC, BRICS and the leading SCO countries.

Therefore, in the context of the Asian vector of the development of the Russian economy, the state authorities of the Siberian and Far Eastern regions should revise the strategic policy documents of the regional level so they will include the activities aimed at activating and stimulating investment from the developing Asian economies.

\section{References}

Federal Information Web Portal "Infrastructure and Public-Private Partnership in Russia". Available at: http://www.pppi.ru/

K Velikomu Okeanu - 2, ili rossiiskii ryvok k Azii. [[Toward the Great Ocean - 2, or Russia's Breakthrough to Asia]. In Doklad Diskussionnogo kluba Valdai [Valdai Discussion Club Report]. Available at: http://vid-1.rian.ru/ig/valdai/Twd_Great_Ocean_2_Rus.pdf

Official website of the Federal State Statistics Agency on the Krasnoyarsk Krai, Republic of Khakassia and Republic of Tyva. Available at: http://www.krasstat.gks.ru/

Priamye inostrannye investitsii v Rossii: regional'nyi aspect. Analitecheskii obzor, aprel' 2014 [Direct foreign investments in Russia: regional aspect. Analytical review, April 2014]. Available at: www.ra-national.ru

RAEX Rating Agency official website. Available at: http://www.raexpert.ru/

Ruiga, I.R. (2015). Monitoring sostoianiia investitsionnoi sfery i realizuemoi investitsionnoi politiki Krasnoiarskogo kraia [Monitoring the state of the investment field and implemented investment policy of the Krasnoyarsk Krai], In European Social Science Journal, 12, 145-159.

Ruiga, I.R. (2016). Methodological Aspects of the Regional Innovative Development Evaluation with Focus on Investment Flows, In Indian Journal of Science and Technology, 9 (37).

Ruiga, I.R., Pimanov, Iu.V, Anisimov, P.E. Bogomolov, V.A., Vekkesser, E.K., Vasil'ev, A.V. (2015). Formirovanie "Shelkovogo meridian Sibiri" v usloviiakh realizatsii global'nogo megaproekta "Novogo shelkovogo puti" [Formation of the "Silk Meridian of Siberia" in terms of implementation of the global mega project New Silk Road"]. In Ekonomika i predprinimatel'stvo [Economics and Entrepreneurship], 11-1, 186-194. 


\section{Региональная инвестиционная политика:}

\section{выбор приоритетов и механизмов взаимодействия}

И.Р. Руйга

Сибирский федеральный университет Россия, 660041, Красноярск, пр. Свободный, 79

Статья посвящчена исследованию действующих механизмов активизации инвестиционной деятельности в Красноярском крае. В статье представлен анализ основных показателей инвестиционной сферы Красноярского края, выявлен ряд негативных тенденций инвестиционного процесса с точки зрения стратегчческого развития региональной экономики. Рассмотрень реализуемые в рамках действующей инвестиционной политики финансовые и нефинансовые инструменты и методы, а также нормативно-правовое обеспечение, посредством которого осуществляется их функционирование. Выявлены преимущества и недостатки действующих мер государственной поддержки инвестиционной деятельности, обозначена необходимость пересмотра направлений реализуемой инвестиционной политики в регионе с учетом мирового опьта и сложившейся положительной практики субъектов Российской Федерации.

Ключевые слова: инвестиционный прочесс, региональная инвестиционная политика, инвестиционные механизмы, Красноярский край.

Научная специальность: 08.00.00 - экономические науки. 